$1-1-2011$

\title{
Muslims in Western Canon Law, 1000-1500
}

David M. Freidenreich

Colby College, dfreiden@colby.edu

Follow this and additional works at: https://digitalcommons.colby.edu/faculty_scholarship

Part of the Religion Commons

\section{Recommended Citation}

Freidenreich, David M., "Muslims in Western Canon Law, 1000-1500" (2011). Faculty Scholarship. 28. https://digitalcommons.colby.edu/faculty_scholarship/28 
a Zoroastrian wet nurse; nāșibī women may not be employed as wet nurses. ${ }^{\circ}$

The slight differences between laws regarding Scripturists and näsibīs do not reflect a modicum of respect toward Jews and Christians on the part of Shĩ jurists. Rather, Shīis ascribe the lowest possible status to näsibīs, a status that in some cases renders Sunnis inferior to Scripturists. Indeed, it seems that Shîi insistence upon treating Jews and Christians as unbelievers is primarily intended to convey a message regarding Sunnis: failure to accept God's designated authority figures, the Prophet and the Imāms, is tantamount to idolatry itself. The fact that Jews and Christians revere an authentic scripture is thus irrelevant. Because Sunnis use reflexive laws governing foodstuffs and marriage as a means of expressing the affinity between Muslims and People of the Book, classical Shi'i authorities are able to employ discourse about the same laws to express the sharp discontinuity not only between Muslims and Scripturists but also between Sunnis and Shicis. Christians and Jews, one might say, are pawns caught in the intra-Islamic crossfire.
Christian-Muslim Relations: A Bibliographical History, volume 3 (1050-1200)_, ed. David Thomas et al. (Leiden: Brill, 2011).

\section{Muslims in Western canon law, 1000-1500}

\section{David M. Freidenreich}

Collections of Latin canon law published from the late $12^{\text {th }}$ through late $15^{\text {th }}$ centuries regularly include a section titled 'On Jews and Saracens and their [Christian] servants' (De Iudaeis et Sarracenis et eorum servis). ${ }^{.}$This title is revealing in several respects. First, it reflects the fact that Roman Catholic canonists active during this period perceived this subject matter as a discrete topic and possessed a significant number of normative statements about it. We should not take this fact for granted: Gratian's Decretum, the foundational text of classical canon law compiled c. 1140, contains a sub-section devoted to Jews but devotes no systematic attention to Muslims; indeed, references to 'Saracens' in this sizeable collection are few and far between." Later collections also incorporate canons related to Muslims under a variety of headings, but the presence of a section devoted to Jews and Saracens serves as an important focal point for medieval analysis of the status of these non-Christians within canon law. Second, this title reflects the fact that canonists are principally interested in Jews and

On the use of this title in $12^{\text {th }}$ - and $13^{\text {th }}$-century collections, see P. Herde, 'Christians and Saracens at the time of the crusades. Some comments of contemporary canonists', in Studien zur Papst- und Reichsgeschichte, zur Geschichte des Mittelmeerraumes und zum kanonischen Recht im Mittelalter, Stuttgart, 2002, pp. 56-57; this essay is a revised version of a work initially published in Studia Gratiana $12(1967)$ 359-76. The Constitutiones Clementinae, published by Pope John XXII in 1317 (1967) 359-76. The Constitutiones Clementy the same title, exclusively to Saracens (Clem. 5.2.un). The 15 -century collection Extravagantes communes employs the title De Iudaeis, even though this section contains a canon that specifically addresses Saracens (Extrav. commun. 5.2.1). On medieval collections of canon law and the forms of citation used in this essay to refer to their contents, see J.A. Brundage, Medieval canon law, London, 1995, pp. 190-202.

Only four canons in the Decretum, all cited below, refer explicitly to Saracens; four additional canons that refer to 'pagans' may well have Saracens in mind. These eight canons (out of a total of nearly 4,000) appear in five different sections of the Decretum. All but one date from the $8^{\text {th }}$ and $9^{\text {th }}$ centuries; these canons receive more sustained treatment in D. Freidenreich, 'Muslims in canon law, 650-1000', CMR1, 83-98. Canons regarding Jews appear in C. $28 \mathrm{q} .1$, which addresses the subject of marriage involving infidels; the absence of canons regarding Saracens in this section of the Decretum is striking.
${ }_{50}$ Al-Tūsī, Al-nihāya, p. 504; al-Nu'mān, Da'āim al-Islām, ii, p. 243, \$914. See further Kohiberg, 'Non-Imāmī Muslims', p. 104. 
Saracens as they stand in relationship to Christians. A major objective of canons addressing Jews and Saracens is to ensure that Christians do not find themselves in any way subservient to non-Christians, although we shall see that Western canon law regarding Muslims advances a variety of other objectives as well. Third, this title reflects the common practice among Western canonists of placing Jews and Saracens in the same category. Given the unique place of the Jews within Christian theology and early medieval canon law, this development is arguably the most surprising feature in the history of medieval canon law regarding Muslims. Tension between the equation of Saracens with Jews and the insistence upon a distinction between these communities of non-Christians animates much of the legal discourse about Muslims in medieval Western Europe.

Bernard of Pavia, originator of the title De Iudaeis et Sarracenis, ${ }^{4}$ also authored the explanation of the term 'Saracens' that became commonplace among canonists: Saracens, who accept neither the Old nor the New Testament, named themselves after Abraham's wife, Sarah, even though they are in fact descended from his maidservant, Hagar, and should therefore properly be called 'Hagarenes' (Agarenos). Despite the awareness of some earlier authorities that Saracens are monotheists - Pope Gregory VII (r. 1073-85), writing to a Muslim ruler, emphasizes that both parties "believe in and acknowledge the one God, albeit in different ways's - Bernard uses the terms Sarraceni and pagani interchangeably, apparently because he accepts the classic Christian notion that non-Christians must be either Jewish or pagan. ${ }^{6}$ Thus, even as Bernard links Jews and Saracens - and, as we

The history of canon law in the Eastern Churches is unrelated to that of the Western tradition; an essay on 'Muslims in Eastern canon law, 1000-1500', is scheduled to appear in the $C M R$ volume covering the period 1200-1500.

${ }_{4}$ Title 5.5 of Bernard's Breviarium extravagantium, also known as the Compilatio prima, published between 1188 and 1192; see E. Friedberg (ed.), Quinque compilationes antiquae, 1882 (repr. Graz, 1956), p. 55.

E. Caspar (ed.), Das Register Gregors VII., MGH Epistolae, 2 vols, 1920 (repr. Munich, 1978), i, p. 288 (JL 4996, written in June 1076). The recipient of this letter was

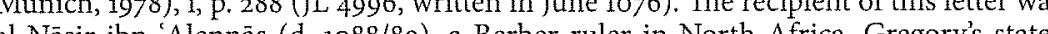
al-Nasir in 'Alenas (d. 1088/89), a Berber ruler in North Afica. Gregory's statement did not enter the canon law tradition; had it done so, the development of West-
ern canon law regarding Muslims would have been quite different.

6 Bernard of Pavia, Summa decretalium (published c. 1191-98), ed. E.A.T. Laspeyres, 1860 (repr. Graz, 1956), 5.5.2, p. 210; Bernard uses the term paganis instead of Sarracenis in 5.5.4-5 and 5.6.1, pp. 211-13. Immediately following his definition of Saracens, Bernard classifies Samaritans, who accept the Five Books of Moses but reject the prophets, as a subset of the Saracens because John 4:9 makes clear that Samaritans are not Jews; they must, therefore, be Saracens/pagans. On Bernard's title, his equation shall see, applies to the latter many of the laws governing the former he defines the two communities as fundamentally different.

The equation of Saracens and pagans is commonplace within medieval Christian legal discourse. ${ }^{7}$ Azo of Bologna (d. c. 1230), in his commentary on the Code of Justinian, declares explicitly that Saracens, "who worship and venerate countless gods, goddesses, and demons', are pagans and are therefore subject to the edicts of Roman law forbidding idolatry. ${ }^{8}$ Hostiensis (d. 1271) repeats Azo's words and makes a point of warning Christian missionaries not to consume food that Saracens have sacrificed to their idols. ${ }^{9}$ Even though many contemporaneous theologians display a more accurate understanding of Islam, medieval canonists seem to have been unable or unwilling to reconsider the traditional presumption that non-Christian gentiles are idolaters. This commitment to the traditional approach to classifying humanity makes the conjoined subject heading 'On Jews and Saracens' all the more intriguing.

The present essay surveys references to Muslims within the normative literature of the Catholic Church: statements of popes incorporated into legal collections ${ }^{10}$ and canons of ecumenical and local

of Saracens and pagans, and the impact of Bernard's definition of Saracens, see B.Z. Kedar, 'De iudeis et sarracenis. On the categorization of Muslims in medieval canon law', in R.I. Castillo Lara (ed.), Studia in honorem eminentissimi cardinalis Alphonsi M. Stickler, Rome, 1992, 207-13 (repr. in his Franks in the Levant, 11th to 14th centuries, Aldershot UK, 1993). The anonymous author of the Summa Elegantius (Coloniensis), written c. 1169, also employs the terms 'pagan' and 'Saracen' as synonyms: see for 66, ed. G. Fransen and Kuttner, 4 vols, Vatican City, 1978, ii, p. 189

See E. Bussi, 'La condizione giuridica dei musulmani ne diritto canonico', Rivista di Storia del Diritto Italiano 8 (1935) 259-63.

${ }^{8}$ Azo of Bologna (d. 1230), Summa aurea on Code 1.11, Lyons, 1557, 5r; see Kedar, 'De iudeis et sarracenis', p. 210 .

Hostiensis (Henry of Susa), Summa aurea, Venice, 1574 (repr. Turin, 1963), 5.6 cols 1524-25; see D.M. Freidenreich, 'Sharing meals with non-Christians in canon law commentaries, circa 1160-1260. A case study in legal development', Medieval Encounters 14 (2008) 41-77, pp. 70, 75-77. On the conceptions of Islam expressed by ecclesiastical authorities, see further $\mathrm{H}$. Gilles, 'Législation et doctrine canoniques sur les Sarasins', in Islam et Chrétiens du Midi (XII ${ }^{-}$-XIV $V^{s}$ s.) (Cahiers de Fanjeaux 18), Toulouse, 1983 , pp. 197-99. On the equation of Saracens with pagans in European literature, see Tolan, Saracens, pp. 105-34.

10 The primary collections of medieval canon law - the Decretum, Decretales, Sextum, Clementines, Extravagantes Joannes, and Extravagantes communes - are found in E. Friedberg (ed.), Corpus iuris canonici, Leipzig, 1879-81 (repr. Graz, 1959). Canons in the 'five early collections' not incorporated into the Decretales may be found in E. Friedberg (ed.), Quinque compilationes antiquae, Leipzig, 1882 (repr. Graz, in E. Friedberg (ed.), Quinque compilationes antiquae, Leipzig, 1882 (repr. Graz,
1956). The notes below indicate the number assigned to each cited papal statement in P. Jaffé, Regesta pontificum Romanorum, ed. S. Loewenfeld et al., 2nd ed., 1885 (repr. 
councils, ${ }^{11}$ along with scholarly commentaries and treatises. ${ }^{12}$ Canon law, as Christian religious law is called, was one of several legal systems simultaneously operative within medieval Europe. Civil authorities established and enforced their own legal systems, built on the foundations of Roman law and local custom; the relationship between canonical and civil norms regarding Saracens depends on a variety of local political factors. ${ }^{13}$ Jewish and Islamic communities in Europe,

Graz, 1956) (siglum: JL), or A. Potthast, Regesta pontificum Romanorum, 1874 (repr Graz, 1957). I have not attempted comprehensive coverage of papal statements that do not appear in legal collections, as this literature is vast. Reference to some of these statements may be found in the entries for individual popes. See also Bussi, 'Condizione giuridica dei musulmani', pp. 490-94, and S. Simonsohn, The Apostolic See and the Jews, 8 vols, Toronto, 1988-91, whose index (s.v. 'Moslems') indicates that over 5\% of the papal documents through 1503 included in this anthology referred to Saracens as well as Jews. Of particular value on this subject is J. Muldoon, 'The Avignon papacy as the frontiers of Christendom. The evidence of Vatican Register 62' Archivium and the fist historiae ponifcia 17 (1979) 125 -95 (repr. in his Canon lam the expansion of Europe and word order, Ald (19rshot UK, 1998 ). Vatican Register 62 , a collection of $14^{\text {-century }}$ papal decretals regarding the frontiers of Christianity, contains a sizeable number of
texts related to Muslims.

${ }^{21}$ The texts of canons from ecumenical councils, along with an English translation, may be found in G. Alberigo et al. (eds), Decrees of the ecumenical councils, trans. N.P. Tanner, London, 1990. Canons from local councils appear in various sources of vary ing quality; I provide reference to the most convenient or most critical edition with which I am familiar. These editions include: A. García y García, 'Jews and Muslims in the canon law of the Iberian Peninsula in the late medieval and early modern period, Jewish History 3 (1988) 41-50; S. Grayzel, The Church and the Jews in the XIIIth century. A study of their relations during the years 1198-1254, based on the papal letters and the A stuliar decrees of the period Philadelphia PA, 1933. M Guallar Pérez (ed.), Los conconcil ar decir en cillos Taraconenses celebrios en Ler Da, Les, legal sources of the ealy Midte A. rum nova et amplissima collectio, Florence, 1759, J.O. Molina (ed.), Sinodo de La Diócesis de Cartagena (1475), Murcia, 2002; J. Tejada y Ramiro (ed.), Coleccion de cánones de todos los concilios de la Iglesia de España y de America, 7 vols, Madrid, 1859-63. C.J Hefele and H. Leclercq, Histoire des conciles, Paris, 1907 (repr. Hildesheim, 1973), is an invaluable finding aid.

11 This research has been aided by the use of text-searchable electronic versions of canon law sources prepared by the author of this essay and by E. Reno III. Downloadable files of works in the public domain are available through the Medieval Canon Law Virtual Library, http://web.colby.edu/canonlaw.

13 Studies that devote significant attention to civil laws regarding Saracens include D. Abula "The servitude of Jews and Muslims in the medieval Mediterranean. OriD. Ab and diffusion' Ḿlanges de l'Ecole Francaise de Rome. Moyen Age 112 (2000) 687gins and difnes ' $714 ;$ N. Berend, At the gate of Christendon. Jews, Mustims a thagans 'medieval Hungary, c. 1000-c. 1300, New York, 2001, J. Boswel, The roy l pasure. Muslim communities under the Crown of Aragon in the fourteenth century, New Haven CT, 1977 R.I. Burns, Islam under the crusaders. Colonial survival in the thirteenth-century King dom of Valencia, Princeton NJ, 1973; M. Nader, Urban Muslims, Latin laws, and lega institutions in the Kingdom of Jerusalem', Medieval Encounters 13 (2007) 243-70; and J.M. Powell (ed.), Muslims under Latin rule, 1100-1300, Princeton NJ, 1990, especially moreover, employed their own laws for internal purposes. Indeed, as John Boswell observes, 'References to Jews and Muslims in medieval documents always refer to peoples not of differing religions, but of different laws, and this concept of legal identity was shared by the minorities themselves. ${ }^{14}$ We should not forget the distinction between Jewish and Islamic law on the one hand and, on the other, "Jewry" and 'Saracen' law, namely Christian laws related to Jews and Muslims respectively. This essay devotes particular attention to assessing the relationship between Saracen law and Jewry law.

\section{Saracens as more threatening than Jews}

The eventual near-equation of Saracen law and Jewry law is especially surprising because the only statement in Gratian's Decretum that addresses both Saracens and Jews emphasizes the disparity in the ways Christians ought to relate to members of these distinct communities. 'There is in fact a difference between the position of the Jews and that of the Saracens. We legitimately wage war against the lastmentioned, who persecute the Christians and expel them from their cities and their own settlements; the afore-named, on the other hand, are willing to serve.'15 This statement by Pope Alexander II (r. 106173) - known as Dispar, the opening word of the extract found in the Decretum - plays a prominent role in discussions among canonists about the threatening Saracen who may justly be attacked and even, according to some authorities, persecuted. ${ }^{16}$ Numerous canons in the Decretum and the Liber extravagantium (or Decretales) of Pope Gregory IX (r. 1229-41) paint pictures of Saracens in violent and deeply threatening hues. Gratian preserves statements that recall the Saracen

the essays by B. Kedar on the Frankish Levant and J.F. O'Callaghan on Castile and Portugal.

${ }^{4}$ Boswell, Royal treasure, p. 131; Boswell proceeds to observe that the theoretical right of Muslims in Aragon to be judged in accordance with Islamic law was often not honored in practice.

${ }^{15}$ C. 23 q. 8 c. 11 (Ivo, Panormia, 8.29); trans. Herde, 'Christians and Saracens' p. 58, who proceeds to survey medieval interpretations of this canon. A complete version of this letter to Spanish or, perhaps, French bishops (JL 4528, dated 1063), which reproaches Christians engaged in the reconquest of Spain for attacking local Jewish communities, appears in the Decretum of Ivo of Chartres, 13.114 (PL 161, col. 824); Simonsohn, Apostolic See, i, 35-36, provides a full text and bibliography.

${ }^{16}$ The summary rubric introducing this canon in the Decretum reads 'We ought not persecute Jews, but rather Saracens. 
invasion of Spain, Provence and Burgundy in the $7^{\text {th }}$ and $8^{\text {th }}$ centuries and their sack of Rome in $846 .{ }^{17}$ Within the Decretales, Pope Alexander III (r. 1159-81) addresses a case involving Saracens in Sicily who are wont to rape or murder Christian women and children. ${ }^{18}$ Pope Celestine III, in a decretal written in 1193, prohibits Saracens who conspire with Christian women to murder their husbands from marrying the widows after these Saracens convert to Christianity. Celestine rules, however, that marriage between a Christian widow and the recently converted Saracen who killed her husband in battle is binding, even if the woman did not realize that she was marrying her late husband's killer. ${ }^{19}$ The spectre of Saracens also hovers over the ruling of Pope Lucius III (r. 1181-85) that a woman may not remarry without certainty regarding her first husband's death. ${ }^{2 \circ}$ Canonical sources never portray Jews as similarly threatening.

Christians may not support Saracen belligerence by selling arms, iron, ships, wood for helmets, or other items that might support Saracen war efforts. Christians are also forbidden from serving on Saracen pirate ships or teaching Saracens how to construct their own naval vessels. Prohibitions against such activity recur frequently in canonical sources. The Third Lateran Council (1179), among the first to address this subject, declares not only that Christians who violate this prohibition are to be excommunicated, but also that churches in maritime towns should publicly identify these excommunicants on a regular basis, that civil authorities should confiscate their possessions,

17 D. 56 C. 10: C. 23 g. 8 c. 7 (see also C. 23 q. 8 d. p. c. 20). See also Oviedo (1050), c. 6 (Linder, Jews in the legal sources, pp. 557-58), which lists attack by Saracens among the small number of grounds justifying Christian travel on the Sabbath

${ }_{18} \mathrm{X}$ 5.17.4 (JL 14044, 1 Comp. 5.14.3). Alexander, responding in 1167 to a query from the archbishop of Palermo, who has been given jurisdiction over such Saracen instructs that ecclesiastical authorities may only levy monetary or moderate corpora punishments and ought to refer serious crimes that warrant capital punishment or permanent bodily injury to the civil authorities

${ }_{19} X_{3.33 .1}$ (JL 17649, 2 Comp. 3.20.2); Celestine rules similarly regarding a Saracen widow who converts and inadvertently marries the Christian soldier who killed her Wirst conversion in canon law' in S. Kuther and $K$. Pennington (eds) Procedings of the sixth international congress of -26 (repr. in his Franks in the Levant)

20 X 4.21.2, a decretal addressed 'to all Christians found in Saracen captivity' (JL 15211, 1 Comp. 4.22.3). See also Raymond of Peñafort (d. 1275), Summa de matrimonio 13.4, ed. J. Ochoa and L. Diez, Rome, 1978, col. 960, who refers to men who go off to battle against the Saracens and are never heard from again. and that captured violators become the slaves of their captors. ${ }^{21}$ The Ordinary Gloss to this canon as it appears in the Decretales calls for capital punishment for Christians who sell arms to Saracens. ${ }^{22}$ Pope Clement III (r. 1188-91) extended this prohibition to cover all commerce with Saracens ${ }^{23}$ and declared that this prohibition continues to apply during periods of truce. Commentators explain that a truce is merely a temporary cessation of hostilities, because peace with Saracens is impossible. Christians may, however, exchange money or goods with Saracens for the purpose of redeeming captives. ${ }^{24}$ The sale

${ }_{21} 3$ Lateran, c. 24 (Alberigo 223; 1 Comp. 5.5.6, X 5.6.6); the interpretations offered by early commentators on this canon are summarized by Herde, 'Christians and Saracens', pp. 63-64. As Gilles observes ('Legislation et doctrine canoniques', p. 196), this canon was incorporated into the civil law codes of Castile and the Kingdom of Jerusalem; Gilles also discusses the application to Saracens of Roman law regarding the sale of arms to barbarians. Similar canons were promulgated at the Council of Narbonne (1195, c. 2; Grayzel, The Church and the Jews, pp. 298-99), the Fourth Lateran Council (1215, in c. 71 [Alberigo, Decrees, pp. 269-70]; X 5.6.17), and at the Spanish council of Lerida (1229, c 35: Guallar Pérez Los concilios Tarraconenses, p. 238), Valladolid of Lerida (122, c. 35; Gulla Pere, Los con ; $x$ 5 (1322, C. 22; Tejada y Raniro, Coleccion de chnones, in, Pp. 501-2), Toledo (1324, C. 8 Tejada y Ramiro, Coleccion de cinones, ili, p. 525), and Cartagena (1475, c. 8; Molina Sinodo de la Diocesis de Cartagena, p. 156). Pope John XXI, in 1317, reiterated this prohibition with specific reference to the Saracens of Granada (Extrav. Joann. 8.un) see also Extrav. commun. 5.2.1, by Pope Clement $V$ (r. 1305-14). See also the decretal of Alexander III (JL 14351-52) found in Collectio Lipsiensis 55.6-7 (Friedberg, Quinque compilationes antiquae, p. 204). A reference to the prohibition against arming Saracens, absent from Gratian's Decretum, already appears in the Summa Parisiensis (D. 45 C. 3), which was published c. 1160 , well before Alexander III convened the Third Lateran Council; see T.P. McLaughlin (ed.), The Summa Parisiensis on the Decretum Gratiani, Toronto, 1952, p. 40. Raymond of Peñafort and Pope Innocent IV list the sale of arms to Saracens among 17 grounds for excommunication (both provide the same list): Raymond, Summa de paenitentia 3.33.10, ed. J. Ochoa and I Diez Rome, 1976, cols 746-50; Innocent IV, Apparatus in quinque libros Decretalium, on X X Chet is also manifest Christianorum cum Sarracenis, which addresses 40 questions about Christian-Saracen relations: nearly half of these questions relate to trade. This work is published in the Ochoa and Diez edition of Summa de matrimonio, cols 1023-36; see also J.V. Tolan, 'Taking Gratian to Africa. Raymond de Penyafort's legal advice to the Dominicans and Franciscans in Tunis (1234)', in A.A. Husain and K.E. Fleming (eds), A faithful sea. The religious cultures of the Mediterranean, 1200-1700, Oxford, 2007, 47-63.

${ }_{22}$ Glos. Ord. to X 5.6.6, s.v. ferrum; Vincentius Hispanus, cited by Herde (see previous note), similarly asserts that Christians who teach Saracens how to build ships are subject to capital punishment.

${ }^{23}$ X 5.6.12 (JL 16634, 2 Comp. 5.4.6).

$24 \mathrm{X}$ 5.6.11 (JL 16619, 2 Comp. 5.4.5). On this canon and its interpretive tradition, see Herde, 'Christians and Saracens', pp. 65-66. see also Raymond of Peñafort Summa de iure canonico 2.38.2, ed. J. Ochoa and L. Diez, Rome, 1975, col. 212. 
of Christian slaves to Saracens is, of course, illegal; violators are subject to excommunication. ${ }^{25}$

The subject of Christians captured by Saracens receives attention from a variety of authorities. Pope Stephen V, writing in $887 / 88$, permits Christians mutilated by their pagan captors to become priests and excuses Christians who commit murder while in Saracen captivity. ${ }^{26}$ Raymond of Peñafort (d. 1275) similarly excuses Christians who steal from Saracens in order to purchase their own freedom, and he permits kidnapping Christians for the purpose of liberating them from Saracen captivity and the resultant danger of practicing idolatry or circumcision. ${ }^{27}$ Huguccio, writing in the 1180 s, declares that the universal law of nations forbids Saracens from selling Christian prisoners of war into slavery, because their war against Christians is not a just war. Christians, in contrast, may sell Saracen prisoners of war into slavery, because their battle against the Saracens is legitimate; Huguccio cites as proof Dispar, the canon with which we began. Interestingly, Huguccio entertains the possibility of a Christian war of aggression in which justice would lie with the Saracens and in which they alone could legitimately sell their prisoners of war into slavery. ${ }^{28}$

${ }^{25}$ Lerida (1229) cc. 35-36 (Guallar Pérez, Los concilios Tarraconenses, p. 238); Valladolid (1322) c. 24 (Tejada y Ramiro, Coleccion de cánones, iii, p. 502). Precedent for the prohibition against selling Christian slaves to pagans is found in the biography of Pope Zacharias (r. 741-52), who redeemed Christians destined for sale to pagans at the hands of Venetian merchants; an extract of this biography, taken from the Liber pontificalis, appears as 1 Comp. 5.5.2. On this canon and its reception by early $13^{\text {th }}$-centory canonists, tury canonists, see Herc 'C 'Ch in CMR 1 . Friars in Tunis enquired about the practice of 'Muling in callors handing ove Christan se 47 in response, as communicated by Raymond or Penafort, is that the person who does so commits a mortal sin but is not subject to excommunication. Raymond, Responsiones ad dubitabilia $\$ 8$ (cols 1026-27); see also Tolan, 'Taking Gratian to Africa, pp. 56-57.

${ }_{26}$ Mutilation: D. 55 C. 11 (JL 3447); murder: D. 50 C. 38 (JL 3433). D 50 C. 36, a canon from the Council of Lerida $(524$, c. 1$)$, addresses the status of captive clerics who commit murder; some authorities exempt such an act from the category of homicide, but Stephen of Tournai, in his comment on this canon, asserts that this interpretation only applies to to clerics captured by Saracens: Summa, ed. J.F. von Schulte, Giessen, 1891 (repr. Aalen, 1965), p. 73

27. Raymond of Peñafort, Summa de paenitentia 2.6.11, cols 535-36. Raymond hesitates, however to permit the kidnapping of Christians justly held by Saracens durthe Christians falling into ing a period of truce when mortal sin. Elsewhere, he declares that plundering Saracen goods dur-89).

stitutes an act of theft and is prohibited by canon law (2.5.18, cols 48 Vati).

p. 49. The earlier Summa Elegantius (Coloniensis), in contrast, declares that Christian
Alexander II, the author of Dispar, is not the only authority to declare that war waged by Christians against Saracens is legitimate, and Huguccio is not the only commentator to limit the scope of such a declaration. Various early $13^{\text {th }}$ century commentaries on Dispar stipulate that such war is only legitimate in response to Saracen aggression or for the purpose of reclaiming formerly Christian territories. ${ }^{29}$ Commentators on the canon of the Fourth Lateran Council (1215) that calls for the Fifth Crusade were also careful to provide both justification for and restraints upon its 'ardent desire to liberate the Holy Land from infidel hands'. ${ }^{30}$ Vincentius Hispanus (d. 1248), for example, explains that Jesus' declaration that God will take the kingdom of God away from the Jews in favor of the Christians (Mt 21:43) applies to all infidels who lay claim to the Holy Land. Vincentius, however, rejects the arguments of those who use this verse to justify Christian expropriation of all infidel possessions. This right, Vincentius asserts, applies only to actions against heretics, against whom the Church may employ material as well as spiritual forms of coercion. Just as Christians may not impose their faith upon Jews or Saracens, they may not seize the property of Jews or Saracens either. Christians may only reclaim territories from which Christians were expelled by Saracens, in keeping with the canon Dispar. ${ }^{31}$

wars of defense against pagan attackers, such as the Saracens, are justified while all pagan war against Christians is unjust; see $12^{*} .10$ (iii, pp. 217-18).

${ }_{29}$ These commentaries include the Glossa Palatina, Ius naturale of Alanus Anglicanus, and Ecce vicit leo, all cited and discussed by Herde, 'Christians and Saracens', pp. 59-60.

${ }^{30} 4$ Lateran, c. 71 (Alberigo, Decrees, pp. 267-71); this canon is repeated verbatim in some editions of the proceedings of the First Council of Lyons (1245; Alberigo, Decrees, pp. 297-301). Other canons that call for crusades were promulgated at the Council of Clermont (1095; see R. Somerville, The councils of Urban II [ Amsterdam, Council of Clermont (107) 1972]), the First Lateran Council (1123, C. 10; Alberigo, Decrees, pp. 191-92), and the Second Council of Lyons (1274, C. 1; Alberigo, Decrees, pp. 309-14). On canon law regarding the crusades, see J.A. Brundage, Medieval canon law and the crusader. Madison WI, 1969.

${ }^{31}$ Vincentius Hispanus, Apparatus in Concilium quartum Lateranense on c. 71, s.v., ad manibus, in A. García y García (ed.), Constitutiones Concilii quarti Lateranensis una cum Commentariis glossatorum, Vatican City, 1981, p. 380. See also Johannes Teutonicus, Apparatus on c. 71, s.v. Ad liberandam (p. 268). Both of these commentaries were written shortly after the Fourth Lateran Council. Laurentius Hispanus (fl. early ${ }^{13^{\text {th }}} \mathrm{c}$.) also holds that Christians have no right to seize Saracen territories that never belonged to Christians if the Saracens do not attack Christians; see Guido de Baysio (Archediaconus), Rosarium on C. 23 q. 7 C. 2, Lyons, 1559 (repr. Frankfurt, 2008), p. 309 r. 
Pope Innocent IV, in his commentary on the Decretales (published c. 1245), offers a highly influential statement regarding the justification of Christian attacks on Saracens or other infidels and the limits of such just wars. In addition to his arguments for the legitimacy of the crusade to the Holy Land, which rest on the fact that Christians once possessed this land and retain legal title to sovereignty over it, Innocent addresses the circumstances in which popes may legitimately send Christian armies into other infidel territories. In doing so, Innocent IV treats Saracens as paradigmatic of all who dwell beyond the reach of Christianity and Christian rule..$^{32}$ The pope, Innocent declares, is ultimately responsible to Christ for the souls of all human beings, Christian or otherwise. For that reason, the pope has an obligation to ensure that non-Christians obey natural law and to enable non-Christians to learn the truth of Christianity so that they may freely choose to accept or reject Christ. (As evidence for papal jurisdiction over all humanity, Innocent IV cites approvingly recent efforts on the part of the Church to censure and burn the Talmud as standing in violation of Old Testament law, which Jews must obey.) If infidel rulers fail to enforce natural law or refuse to allow Christian missionary activity in their territories, popes may justly authorize the use of force in support of their efforts to carry out the papacy's God-given responsibilities. Innocent emphasizes, however, that infidels and Christians alike possess the right to private property and self-government and that popes may not act in contravention of these rights beyond the degree necessary to fulfil papal responsibilities. ${ }^{33}$

32 Innocent IV is not the first to do so; Huguccio, writing c. 1180, treats Saracens as 3a Innocent IV is not the found by Roman law emblematic of those who do not accept and hirum [ed. Prerovský, Vatican City, 2006 (Summa decretorum on D.1 c. 12, s.v. ins Quitum the Tatars, the Lithuanians, and the p. 56]). Innocent's logic is ultimately applied to the Tatars, the the non-Muslims; inhabitants of the Canary lslands and the New Word, anong other non-Muslims; in addition to the sources cited in the following note, see J. Muldoon, "Papal responsibility for the infidel. Another look at Alexander Vis Inter Review 64 (1978) 168-84 (repr. in Muldoon, Canon law).

${ }_{33}$ Innocent IV, Apparatus in quinque libros Decretalium, on X 3.34.8, Frankfurt 1570 (repr. Frankfurt, 1968), pp. $429 \mathrm{~V}-43 \mathrm{Ov}$. A detailed explanation of this text appears in J. Muldoon, Popes, lawyers, and infidels. The Church and the non-Christian world 1250-1550, Philadelphia PA, 1979, pp. 6-15; Muldoon proceeds to document the interpretation and application of Innocent's ideas through the $15^{\text {th }}$ century. An edition of

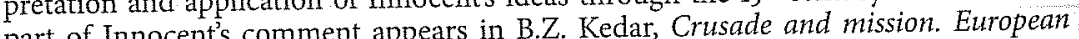
part of Innocents the Muslims, Princeton NT, 1984, p. 217; see also Kedar's discusapproaches town the Mrundage, 'Holy war sion on pp. 159-61. Extracts of this comby (ed), The holy war. Columbus $\mathrm{OH}_{1976}$, and the medieval lawyers, in T.P. Mu rilar argument see Giovanni degnano, Tractatus de bello, de reprehesaliis et de duello, ed. T.E. Holland, Oxford, 1917, pp. 91-93
Various canonists offer more expansive justifications for war against Saracens and other infidels. Hostiensis holds that infidels have no rights to property and self-government: because Christ has dominion over the entire earth, he and his vicars, the popes, have the right to deprive infidels of their possessions and sovereignty in favor of Christians. ${ }^{34}$ Hostiensis takes for granted that crusades may be preached against Saracens and heretics alike. ${ }^{35}$ Similarly, Oldradus de Ponte (d. c. 1337) argues that it is always legitimate for Christians to wage war against Saracens because the latter, as heirs to Ishmael's belligerent legacy, always attack Christians or await the opportunity to do so. Even if Saracens were to desire true peace, Oldradus states, Christians would still be justified in fighting to regain sovereignty over Spain, 'the homeland of which we were violently despoiled. ${ }^{36}$ Oldradus proceeds to assert by means of biblical proof-texts that Christ has been praised throughout the earth and, thus, that Christians may justly reclaim all territories. ${ }^{37} \mathrm{He}$ depicts Saracens as 'beasts deprived of reason' who are subject to the dominion of the Church on account of their animalistic nature and the universal sovereignty of Christ and his vicar, the pope. Oldradus further supports these unusually broad claims by reference to the biblical passage that places Hagar (the Saracens) at the mercy of Sarah (the Church) as a slave who may justly be beaten, expelled and deprived of property. ${ }^{38}$ Elsewhere, Oldradus holds that Christian rulers have the right to expel their Jewish and Saracen subjects but ought not to do so without cause. ${ }^{39}$

(trans., pp. 232-33); for a summary and comparison with Innocent's argument, see Muldoon, Popes, lawyers and infidels, pp. 21-23.

${ }^{34}$ Hostiensis, In tertium Decretalium librum Commentaria [Lectura] on X 3.34 .8 , Venice, 1581 (repr. Turin, 1965), pp. 128r-129r, summarized by Muldoon, Popes, lawyers, and infidels, pp. 15-17, and Brundage, 'Holy war', p. 122 (extracts in pp. 137-38, nn. 144, 156-57).

${ }_{35}$ Hostiensis, Summa aurea on X 3.34 , \$19 (col. 1141); the relevant passage is quoted in Brundage, 'Holy war', p. 139, n. 170 .

${ }^{36}$ The Second Lateran Council (1139), in passing, equates the conquest of Jerusalem and the conquest of Spain (c. 18 [Alberigo, Decrees, p. 201]; C. 23 q. 8 c. 32); Oldradus seizes upon this passage to demonstrate the importance of the latter.

${ }^{37}$ Oldradus is not the first to endorse such a claim which, according to Herde ('Christians and Saracens', p. 6o), satisfied few canonists.

${ }^{38}$ Oldradus de Ponte, Consilium 72, in N. Zacour, Jews and Saracens in the Consilia of Oldradus de Ponte, Toronto, 1990, pp. 80-82 (Latin), 47-53 (English; the cited passages follow Zacour's translation). On this text, see also Muldoon, Popes, lawyers, and infidels, pp. 18-21.

${ }_{39}$ Oldradus, Consilia 87 and 264, in Zacour, Jews and Saracens, pp. 83-84, 8689 (Latin), 54-58, 62-67 (English); see also Zacour's discussion of these consilia, pp. 26-30. 
Though they differ over the details, all canonists regard military efforts to reclaim Spain and the Holy Land from the Saracens as legitimate and, indeed holy: 'war that was not merely justifiable but justifying and spiritually beneficial to those who participated, in the words of James A. Brundage..$^{\circ}$ The most significant of these spiritual benefits took the form of a commutation of penance or remission of temporal punishment for sin bestowed upon Christian soldiers fighting in such wars. Because wars against Saracens are just, ecclesiastical and civil authorities alike have the right to levy special taxes to support these efforts. ${ }^{41}$ The prohibition against usury does not apply to loans that Christians extend to those with whom war is justified, including Saracens. $^{42}$ Without precedent, ecclesiastical authorities took active if indirect roles in the prosecution of war with the Saracens; a small number of canonists even suggest that stringent norms forbidding clerics from taking up arms may be relaxed in such contexts. ${ }^{43}$ Especially deadly weapons such as the crossbow, forbidden for use against Christians, may be employed in battle against 'pagans and those who persecute

$4^{40}$ Brundage, 'Holy war', p. 100; Brundage addresses attitudes toward the legitimacy of wars against Saracens on pp. 120-22. On these spiritual benefits in general and those associated with the 'crusade indulgence' in particular, see Brundage, Medieval canon law and the crusader, pp. 139-58.

${ }^{41}$ Raymond, Summa de paenitentia 1.14.4, col. 408 (ecclesiastical authorities); 2.5.13 and 2.5.15, cols 478-83 (civil authorities). See further D. Nirenberg, 'Christendom and Islam, in M. Rubin and W. Simons (eds), Christianity in Western Europe, C. 1100c. 1500 (Cambridge History of Christianity 4), Cambridge, 2009, 149-69, pp. 157-58. In 2.514 Raymond states that Saracen authorities may justly assess taxes or tolls on Christians travelling in Saracen lands during times of truce, provided that the Saracen government ensures the safety of those Christians.

cen ${ }_{42}$ C. $14 \mathrm{q} .4 \mathrm{C}, 12$, which Rufinus applies specifically to Saracens and heretics (ed. ${ }^{42}$ C. 14 q. 4 C. 12, which Rufinus applies specifically to Saracens and heretics (ed.
H. Singer, Paderborn, 1902 [repr. Aalen, 1963], p. 342). See also Bernard of Pavia, Summa decretalium 5.15 .5 (p. 235) and 5.5.4 (p. 211) who, in 5.5.4, also authorizes civil authorities to impose heavy financial penalties on subject Saracens, citing C. 23 q. 6 C. 4. On this canon, see also Guido de Baysio, Rosarium (p. 308v). Alexander III, however, stipulates that Christians may not lend money at usurious rates of interest to Christian who seek to ransom co-religionists held in Saracen captivity (JL 14042, I Comp. 5.15.5, X 5.19.4). On the subject of usury, see also the Summa of Sicardus of Cremona on C. $23 \mathrm{q}$. $8 \mathrm{c}$. 11, quoted and discussed by Herde, 'Christians and Saracens', p. 60.

${ }_{43}$ See Brundage, 'Holy war', pp. 111-12, and, in greater detail, R. Castillo Lara, Coaccion ecclesiastica y sacro Romano imperio, Turin, 1956, pp. 74-105. Rufinus, in his Summa decretorum (published 1164) speaks caustically about those who allow certain types of clerics to bear arms, yet even he grants an exception to those who fight [repr. Aalen, 1963], p. 412) adherents of our faith'; the latter phrase may allude specifically to Saracens, as depicted in Dispar.44

The canons we have surveyed thus far address Saracens whose belligerent behavior conforms to the depiction offered in Dispar, behavior that differs significantly from that associated with Jews. Commentators on this canon itself, however, interpret Alexander II's statement as conditional: if Saracens persecute Christians, Christians may legitimately wage war against them, but Saracens who are docile like the Jews are to be treated in the same manner as the Jews. The Ius naturale of Alanus Anglicanus (second recension, 1205) supports this argument by reference to a law from the Code of Justinian prohibiting Christians from disturbing peaceful Jews or pagans. ${ }^{45}$ Similarly, the anonymous author of Summa Permissio quaedam asserts that there is no difference between Jews and Saracens as such: Christians should wage war against any non-Christian who persecutes and expels Christians, but not against those who are peaceful. ${ }^{46}$ The Ordinary Gloss to the Decretum makes the same point, even as it distinguishes Saracens from Jews: 'it is clear that if Saracens do not persecute Christians, we may not attack them and, indeed, are permitted to partake of their meals.' This permission, we shall see, applies to pagans but not to Jews. ${ }^{47}$

\section{Saracens as equivalent to Jews}

Canonists utilize legal literature regarding Saracens who dwell beyond the reach of Christian rule as the basis for legal discourse regarding Christian relations with other infidel peoples and rulers; this discourse, in turn, contributes to the emergence of European

\footnotetext{
44 Raymond, Summa de paenitentia 2.4.1, col. 641; Goffredus de Trano, Summa
super titulis Decretalium on X 5.15 .1 (Lyons, 1519 [repr. Aalen, 1968], p. 191r). Both are super titulis Decretalium on X 5.15 .1 (Lyons, 1519 [repr. Aalen,
cited and discussed in Brundage, 'Holy war', pp. 115, 133, n. 113.

t5 Alanus, Ius naturale on C. 23 q. 8 c. 11, citing Code 1.11.6; these texts are quoted
cited and discussed in Brundage "Holy war, pp. 115, 133, n. 113. ${ }^{15}$ Alanus, Ius naturale on C. 23 q. 8 c. 11, citing Code 1.11.6; these texts are quoted
and discussed by Herde, 'Christians and Saracens', p. 58 . See also Gilles, 'Legislation et doctrine canoniques', pp. 200-1.

${ }^{46}$ See Herde, 'Christians and Saracens', p. 6o. Innocent IV similarly distinguishes between belligerent and submissive Saracens; see Apparatus on X 3.42 .3 (p. $456 \mathrm{r}$ in the Frankfurt 1570 ed., which identifies this as c. 4).

${ }^{47}$ Glos. ord. on C. 23 q. 8 C. 11, s.v. persecuntur; this comment, which proceeds to cite Code 1.11.6, was authored by Johannes Teutonicus (c. 1215). Elsewhere, however,
} Johannes prohibits commensality with Jews and Saracens alike; see n. 99. 
international law..$^{48}$ In contrast, with respect to Saracens who dwell within the lands of Western Christendom, canonists turn instead to established Jewry law, treating subject Muslims as equivalent to subject Jews in nearly all respects. ${ }^{49}$ They do so not only because Muslims and Jews alike are not Christians, but also because canonists perceived Saracens themselves to have embraced aspects of Judaism.

Canon law and late antique Roman law alike prohibit Jews and other non-Christians from owning Christian slaves. Canonical sources also forbid Christians from accepting employment as domestic servants or wetnurses in Jewish households and from living with Jews..$^{50}$ These prohibitions reflect not only beliefs regarding Christian inferiority to Jews, but also concerns about the possibility that close relationships between Christians and their Jewish employers might result in the Christians' conversion to Judaism. Beginning with the Third Lateran Council of 1179 , various authorities apply these prohibitions to Jews and Saracens alike. ${ }^{51}$

At about the same time, Huguccio discusses and dismisses a possible distinction between Jewish and Saracen slave-owners. Because

${ }^{48}$ See Muldoon, Popes, lawyers, and infidels.

49 On this phenomenon, see also Bussi, 'Condizione giuridica dei musulmani', pp. 466-69. Linder, Jews in the legal sources, provides a comprehensive collection of Latin canon law regarding the Jews through 1100.

$5^{\circ}$ On laws regarding Jewish slaves and servants, see W. Pakter, Medieval canon law and the Jews, Ebelsbach, 1988, pp. 84-140. A statement of Roman law forbidding nonChristian possession of Christian slaves may be found at Code 1.10.1.

${ }_{51}$ The Third Lateran Council (c. 26 [Alberigo, Decrees, pp. 223-24], 1 Comp. 5.5.5, $X$ 5.6.5) prohibits the employment by Jews and Saracens of Christian servants or $X$ 5.6.5) prohibits the employment buch foreigners. Alanus wetnurses and exconn and Tancred, comment tion against condominiun, see Herde, CChristans and Sach $p$. 62 . The prohibition against domestic servants is reiterated at the Council of Montpellier $(1195, \mathrm{C} .9$ Grayzel, The Church and the Jews, pp. 298-99). The Councils of Tarragona (1239, c. 4 Tejada y Ramiro, Coleccion de canones, iii, p. 368) and Salamanca (1335, C. 12; Tejada y Ramiro, Coleccion de cánones, iii, p. 575) reiterate the prohibition against wetnurses canon 4 from Tarragona and c. 1 of the Council of Avila (1481; García y Garcia, 'Jews and Muslims, p. 45) prohibit living with Jews and Saracens. The Council of Palencia $(1388$, c. 5; Tejada y Ramiro. Coleccion de cánones, iii, pp. 617-18) goes further and requires Jews and Saracens to live in a separate quarter of town from Christians, and

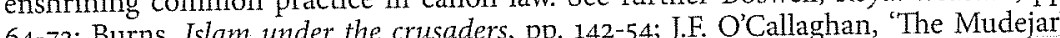

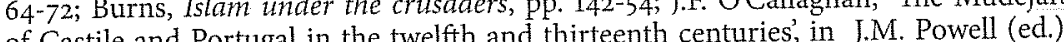
I Castile and Portugal in Muslims under Latin rule, $1100-1300$, Princeton $N$, 19) compares Jews and Saracens in (Potthast, Regesta pontificum, 2565, 3 Comp. 5.3.tn) compares decretal that forbids Christians to serve as wet nurses in Jewish households but does not apply that prohibition to Saracens houses; no reference to Sag extract found in the Decretales (X. 5.6.13)
Paul (or the author of the Pastoral Letters) instructs Christian slaves to submit even to unbelieving masters (1 Tim 6:1), there are grounds for ruling that a pagan born into slavery to a pagan master should remain in slavery even after converting to Christianity. Huguccio accepts this logic in principle but rules that, today, one can find no teaching that servitude to pagans is different from servitude to Jews, for nearly all contemporary pagans judaize: they are circumcised, they distinguish among foods, and they imitate other Jewish rituals. There ought not be any legal difference between them. ${ }^{52}$

According to Huguccio, contemporary 'pagans' - clearly a reference to Muslims - have embraced 'Jewish' practices such as circumcision and adherence to quasi-biblical food restrictions, and for that reason no longer constitute a distinct subset of humanity for normative purposes. Just as a Jew may never own a Christian, even if that slave was born into slavery as a pagan, a Saracen may never do so either The application to Saracens of all Jewry law regarding Christian slaves becomes normative among canonists. ${ }^{53}$ Medieval authorities also apply to Saracens other aspects of Jewry law that seek to prevent Jews from exercising power over Christians or developing unduly intimate relationships with Christians. Thus, for example, the Fourth Lateran Council (1215) reaffirms a $6^{\text {th }}$-century canon forbidding the appointment of Jews to public office and proceeds to extend that prohibition to 'pagans' as well. ${ }^{54}$ Canonists similarly apply to Saracens long-standing restrictions on the rights of Jews in court cases involving Christians. ${ }^{55}$ The prohibition against Christian use of Jewish doctors is also

52 Huguccio, Summa decretorum, D. 54 c. 13, d. a. v. Hoc tunc; the Latin of this passage is reproduced in Pakter, Medieval canon law and the Jews, p. 119, n. 109. Similarly, Tancred (d. c. 1236) justifies the application to Saracens of the prohibition against livlancred (d. c. 1236) justifes the application to Saracens of the prohibition against living 1 Comp. 5.5.5 (3 Lateran, c. 26) as cited in Herde, 'Christians and Saracens', p. 62, n. 44.

See Glos. ord, D. 54 c. 13, d. a. v. Hoc tunc; Raymond of Peñafort, Summa de paenitentia 1.4.6 (cols 314-15). Bernard of Pavia, Summa decretalium 5.5.5 (p. 212), also makes no distinction between Jewish and 'pagan' slave-owners in his discussion of 'Iudaeis et Sarracenis', albeit without considering the grounds on which such a distinction might be made.

${ }^{54} 4$ Lateran, c. 69 (Alberigo, Decrees, pp. 266-67; 4 Comp. 5.4.2, X 5.6.16). See also Montpelier (1195), c. 9 (Grayzel, The Church and the Jews, pp. 298-99); X 5.6.18 (a decretal of Gregory IX, Potthast, Regesta pontificum, 9673); Valladolid (1322) c. 22 (Tejada y Ramiro, Coleccion de cánones, iii, p. 500). These sources all refer explicitly to Saracens. On the controversy surrounding Jews and Saracens holding public office in Hungary, see Berend, At the gate of Christendom, pp. 85-86.

${ }_{55}$ On these restrictions, see Pakter, Medieval canon law and the Jews, pp. 155-220. Tancred asserts that infidels are not entitled to testify in court against Christians, despite the presumption of such testimony in earlier sources; see Herde, "Christians 
extended to Saracen physicians; the Council of Salamanca (1335) explains this prohibition by observing that Jews and Saracens seek to kill Christians. ${ }^{56}$ The canon in the Decretum that forbids the use of Jewish doctors also prohibits Christians from going to the public baths alongside Jews and from consuming Jewish unleavened bread (understood by Western Christian authorities as a reference to all Jewish food); canonists apply these prohibitions to Saracens as well.57 Medieval authorities not only extend the longstanding prohibition against sexual intercourse between Christians and Jews to apply to Christian-Saracen relations, ${ }^{58}$ but also craft a new regulation designed to prevent such intercourse: Jews and Saracens alike must dress in a manner distinct from their Christian neighbors. ${ }^{59}$

and Saracens', p. 63, n. 49, and see also Gilles, 'Legislation et doctrine canoniques' and Sartentia 1.9.8 (col. 370), allows p. 207, n. 81. Ray

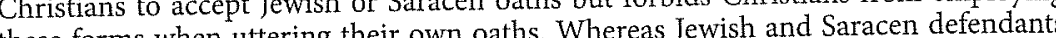
these forns when utering their ow formerly had the right to demand that co-religionists testify against then, Clement decreed that the testimony of Christians alone was also sufficient to secure a convic tion (Clem. 2.8.1)

${ }_{56}^{6}$ Salamanca (1335), c. 12 (Tejada y Ramiro, Coleccion de cánones, iii, p. 575); see also Valladolid (1322), c. 22 (Tejada y Ramiro, Coleccion de cánones, iii, p. 501).

57 C. 28 q. 1 c. 13. On the application of this canon to Saracens, see Bernard of Pavia, Summa decretalium 5.5.4 (p. 211), and Raymond of Peñafort, Summa de Paenitentia 1.4.3 (col. 311); the former seems to extend to Saracens the rules about Jewish doctors and Jews in public office as well. On the interpretation within the Latin Christian tradition of this canon's prohibition of unleavened bread, see Freidenreich, 'Sharing tracition The Council of Cartagena (1475, cc. 86-87; Molina, Sinodo de la Diócesis de mears. The Co 155 - 6 ) prohibits both the purchase of meat prepared by Jews or SaraCartagena, Pp. $155-56$ ) profibith cens and the friltation of such activity. On issures Jews, see D. Freidenreich, Foreigners and their food. Constructing

Christian and Islamic law, Berkeley CA, forthcoming 2011, ch. 12.

${ }^{58}$ Numerous canons forbid intercourse or marriage between Christians and Jews, in the Decretum alone, see C. 28 q. 1 cc. 10, 15, 17. On this subject, see J.A. Brundage, 'Intermarriage between Christians and Jews in medieval canon law', Jewish History 3 (1988) $25-40$. The earliest specific reference to a prohibition against intercourse between Christians and Saracens with which I am familiar appears in the canons of the Council of Nablus (1120, cc. 12-15; c. 16 is the earliest canonical source for the requirement that Saracens wear different clothing from Christians). On the canon ref this council, including an edition, see B.Z. Kedar, 'On the origins of the earliest of this council of Nablus, 1120', Speculum 74 laws (1999) 310-35 (repr. in his Fration, Aldershot UK, 2006). Other canons forbidding interStudies in ronter acculturation, Aldershor UK, course between Christians and Saracens incluns cited in the following note.

Los concilios Tarraconenses, p. 222), and the canons cited in the following note.

${ }_{59}$ The most influential canon on this subject is that of the Fourth Lateran Council (c. 68 [Alberigo, Decrees, p. 266], Comp. 4, 5.4.1, X 5.6.15); on the earliest such canon, see the previous note. On $X$ 5.6.15, see Bussi, 'Condizione giuridica dei minsulmani', pp. 465-66. Additional canons regulating Jewish and Saracen clothing include
Bernard of Pavia seems to apply to Saracens the long-standing rules that allow Jews the freedom to worship in accordance with their own rite and that protect existing synagogues from destruction, but forbid Jews from constructing new synagogues. Raymond of Peñafort, who expands upon this section of Bernard's work, makes clear that these rules apply specifically to Jews but fails to address the status of Islamic worship or mosques. ${ }^{60}$ The Council of Vienne's prohibitions against loud invocations of 'Machometus' and against public pilgrimage to the shrine of a Saracen saint parallel similar restrictions against displays of Jewish worship that might offend Christian passers-by. ${ }^{61}$ Sources from the early Middle Ages forbid Jews from appearing in public at Easter-time lest their presence provoke their Christian neighbors; the Fourth Lateran Council applies this prohibition to Jews and Saracens alike. ${ }^{62}$ On similar grounds, the Council of Compostella forbids Jews and Saracens to live alongside churches or cemeteries. ${ }^{63}$ Clerics gathered at the Councils of Valladolid (1322) and Avila (1481) prohibit Jews and Saracens from being present in church during the mass and, objecting to the common Christian practice of compelling Jews and Saracens to assume humiliating roles in Christian holiday

Tarragona (1239), c. 4 (Tejada y Ramiro, Coleccion de cánones, iii, p. 367), and Avila (1481), c. 5 (García y Garcia, 'Jews and Muslims', pp. 47-48). On the application of the requirement for distinctive clothing in Aragon, see Boswell, Royal treasure, pp. 330-32. On the efforts of papal legates to impose this requirement upon Jews and Muslims in Hungary, including excerpts from the Synod of Buda (1279), see N. Berend, 'Medieval patterns of social exclusion and integration. The regulation of non-Christian clothing in thirteenth-century Hungary', Revue Mabillon n.s. 8 (69) (1997) 155-76; Berend also offers a general survey of Christian efforts to regulate the dress of non-Christians.

6o Bernard of Pavia, Summa decretalium 5.5.4 (pp. 211-12); Raymond of Peñafort, Summa de paenitentia (1.4.3, col. 311)

${ }_{61}$ Vienne (1311-12), c. 25 (Alberigo, Decrees, p. 380; Clem. 5.2.un). At least one com${ }^{61}$ Vienne (1311-12), c. 25 (Alberigo, Decrees, p. 380; Clem. 5.2.un). At least one com-
mentator, however, interpreted this canon as a prohibition against all Islamic worship, mentator, however, interpreted this canon as a prohibition against all Islamic worship,
public or private: Jesselin de Cassagnes (d. 1334/5), paraphrased in Gilles, 'Legislation et doctrine canoniques', p. 204. On this canon and its ordinary gloss, see Bussi, 'Condizione giuridica dei musulmani', pp. 479-88. Even restrictions on worship in public contravene the surrender terms offered to Muslim communities in Spain by their Christian conquerors. Many civil authorities there sought to evade or ignore the demands of clerics regarding this subject but ultimately capitulated. See Boswell, Royal treasure, pp. 261-67; Burns, Islam under the crusaders, pp. 187-92. See also M.T. Ferrer i Mallol, Els sarrains de la corona catalano-aragonesa en el segle XIV: segregacio i discriminació, Barcelona, 1987, pp. 87-95, summarized in RI. Burns 'Muslims in the thirteenth-century realms of Aragon. Interaction and reaction' in JM. Powell (ed) Muslims under Latin rut, 1100-1300, Princeton NT, 1990, 57-102, p. 95. I anell (ed.) of of canonical legislation that addresses the legality of confiscating mosques and con-

verting them to other uses, a common occurrence in Christian Spain,

${ }_{62} 4$ Lateran, c. 68 (Alberigo, Decrees, p. 266; 4 Comp. 5.4.1, X 5.6.15)

${ }^{63}$ Salamanca (1335), c. 12 (Tejada y Ramiro, Coleccion de cánones, iii, p. 575) 
parades, insist that non-Christians may not participate in such events in any capacity. ${ }^{64}$

Although Jews and Saracens are emphatically not members of the Church, they are nevertheless obligated to pay tithes to the Church; the purpose of this requirement, according to Joseph O'Callaghan, was to prevent Christian land-owners from using Jewish or Saracen tenants as a tax shelter. ${ }^{65}$ The imposition of this tithe on Jews apparently originates in a decretal of Alexander III (r. 1059-81). ${ }^{66}$ By the turn of the $13^{\text {th }}$ century, however, this rule was understood to apply to Saracens as well: in 1205, for example, Innocent III scolded the king of Castile for refusing to compel his Jewish and Saracen subjects to pay the tithe. ${ }^{67}$ Later popes instead authorized clerics themselves to force non-Christians to pay the tithe. ${ }^{6}$ This and other canonical regulations governing the behavior of Jews and Saracens, canonists observe, constitute exceptions to the general rule that canon law does not apply to non-Christians. ${ }^{69}$ Clerical officials obviously cannot impose

${ }_{64}$ Valladolid, c. 22 (Tejada y Ramiro, Coleccion de cánones, iii, p. 499); Avila, cc. 4, 6 (García y García, 'Jews and Muslims', pp. 47-48).

${ }_{5}$ This interpretation is supported by 4 Lateran, c. 53 (Alberigo, Decrees, p. 259; X 3.30.32), which requires landlords who assign lands to Christians exempt from the tithe to make good on the revenue lost to the church. Innocent IV, Super decretalibus on X. 3.30.32, applies this canon to Jewish and Saracen tenants.

${ }_{66} \mathrm{X} 3.30 .16$ (JL 13975, 1 Comp. 3.26.28). The requirement that Jews pay the tithe is reiterated in 4 Lateran (1215), c. 67 (4 Comp. 5.7.3, X 5.19.18).

67 Potthast, Regesta pontificum, 2487, cited and translated in Grayzel, The Church and the Jews pp. 112-13, for an edition and bibliography see Simonsohn, Apostolic See, and the Je ', pp. 85-86. On the imposition of the the upon M'Callo "Mudejars of Castile and Pon of the the III ruled in 1199 that Moors who acquired land firom Numerous Spanish church councils reiterated the obligation of Jews and Saracens alike to pay the tithe, including Valladolid (1228), c. 8 (Tejada y Ramiro, Coleccion de cánones, iii, p. 327); Lerida (1229), c. 15 (Guallar Perez, Los concilios Tarraconenses, p. 233); Lerida (1293), c. 3 (Guallar Perez, Los concilios Tarraconenses, pp. 240-41), which addresses Saracens alone; Avila (1384), in T. Sobrino Chomón, 'Constituciones sinodales Abulenses de 1384, Hispania Sacra 15 (1962) 453-67, p. 462.

${ }_{68}^{68}$ See the decretal of Gregory IX to the bishop of Baeza (1233) and that of Innocen IV to the dean of the church of Toledo (1245), in Grayzel, The Church and the Jews, pp. 194-95, 286-87. editions of these texts with bibliography appear in Simonsohn, Apostolic See, i, pp 140, 202-3.

69 Canonists commenting on 1 Comp. 5.5.5 or X 5.6.5, including Ricardus Angli(Cans "Christians ond Saracen, $\mathrm{pp}$. 62-63) and the Ordinary Gloss to the cus (see Herde, 'Chrstians and Sarate Decretales (s.v. permiltantur), compile hists of these exceptions; sist Summa aurea, Lib. 5, De ludatis et Saracenis, 5947 (cols $1519-22$ ). These lists of canons that apply to non-Christians consist primarily of canons originally applicable to Jews alone; their compilers do not specify whether they believe that these canons in fact apply to all non-Christians. The Ordinary Gloss (on X. 4.19.8, s.v. constitutionibus) also holds that Christian authorities may indirectly impose upon non-Christian spiritual punishments such as excommunication upon Jews or Saracens; for both legal and practical reasons, such officials are generally unable to impose material punishments directly upon non-Christians either. Over the $12^{\text {th }}$ and $13^{\text {th }}$ centuries, however, these officials begin to impose upon Christians a boycott against disobedient non-Christians and, as in the case of Innocent III's letter, apply pressure upon secular rulers and judges to enforce the Church's edicts. ${ }^{7 \circ}$

Oldradus de Ponte justifies the imposition of church tithes on Saracens, even those who work land they have occupied since before the Reconquista, by comparing the tithe to the tribute owed to a proprietor, in this case God. Oldradus asserts that violation of this obligation, even by a non-Christian, constitutes an offense subject to ecclesiastical jurisdiction; he also instructs church officials to punish Christian landlords who provide recalcitrant Saracens with lands to work. Oldradus observes that tribute to the secular king does not absolve the Saracen of the responsibility to pay the tithe, and that 'Saracen' land in the Mediterranean region is in fact 'Christian' land subject to divine law, both for historical reasons and because the land is currently ruled by Christians..$^{71}$ Oldradus is not the only Christian authority to claim that the right of subject Saracens to their own property is mediated through Christian institutions. David Abulafia has shown that secular authorities extended to Saracens the status of servi regiae camerae (imprecisely: 'serfs of the royal treasury') that originally applied specifically to subject populations of Jews; some ecclesiastical authorities do the same..$^{72}$ Ecclesiastical authorities devote considerable attention to the conversion of Saracens and the regulations governing such converts. After all, as Johannes Teutonicus observes, the

subjects certain norms absent from Jewish and Saracen laws, such as limitations on Jewish money-lending and on Saracen polygamy. On this final comment, see J. Muldoon, 'Missionaries and the marriages of infidels. The case of the Mongol mission' doon, Missionaries and the marist 35 (1975) 125-41, p. 131 .
The Jo

The Jurist 35 (1975) 125-41, p. 131 .
to On the development of claims for canonical jurisdiction over individual Jews, see Pakter, Medieval canon law and the Jews, pp. 40-69. Raymond of Peñafort, Summa de paenitentia 1.4.4 (col. 312), apparently understands this jurisdiction to apply equally to Saracens; see also the following note. On the roles of secular authorities in enforcing canonical norms applicable to Saracens, see Gilles, 'Legislation et doctrine canoniques', p. 204.

Oldradus, Consilium 91, in Zacour, Jews and Saracens, pp. 85 (Latin), 59-61 (English). OIdradus here applies to Saracens a canon that allows ecclesiastical courts to try Jews for certain offenses against the church $(X$ 5.6.14)

72 Abulafia, 'Servitude of Jews and Muslims.' Among canonists who endorsed the application of this status to Saracens was Pierre d'Estaing (d. 1377), in his commentary on Clem. 5.2.un; see Gilles, 'Legislation et doctrine canoniques', p. 205. 
biblical injunction to love one's neighbor applies to Jewish and Saracen neighbors as well (albeit only 'according to the individual's station'). ${ }^{73}$ Canonists once again draw upon established Jewry law when discussing conversion of the Saracens, most notably in their insistence that conversion must result from a voluntary choice and not from compulsion. ${ }^{74}$ Benjamin Z. Kedar observes, however, that medieval canonists express increasing tolerance toward the use of coercion to encourage the conversion of Saracens and Jews alike..$^{75}$ Numerous councils decree that baptized Jews or Saracens should not suffer a loss of their possessions or their inheritance on account of their conversion which, after all, ought to improve their status; one stipulates that poor converts are eligible to receive support from the church's charitable activities. ${ }^{7}$ Baptism may be performed by anyone, a point Innocent IV illustrates with the example of baptism performed by an infidel Saracen. ${ }^{77}$

We have observed above that Innocent IV regards missionary activity to Saracens and other infidels as a fundamental obligation of the Church and deems obstruction of such activity to be a casus

${ }_{73}$ Glos. ord., D. 2 de pen., c. 5, s.v. participes; cited and translated in Brundage, 'Intermarriage', p. 26.

74 Interpreters who explicitly apply to Saracens the classic legal statements opposing forced conversion of the Jews include the author of the Summa Parisiensis on D. 45 c. 3 (p. 40); Bernard of Pavia, Summa decretalium 5.5.3 (pp. 210-11); Raymond of Peñafort, Summa de paenitentia 1.4.2 (cols 309-10). See also Innocent IV, Apparatus, and Johannes de Ancona, Summa iuris canonici, both on 3.34.8. Johannes' opinion is and Johan iscussed by Kedar; see the citation in the following note. Raymond, reprinted and disctissed bus infants to baptize however, advises Christis in the children surreptitiously, so that the souls of those children who happen to die bilia \$9, col. 1027; see Tolan, 'Taking Gratian to Africa', p. 59).

is Kedar, 'Muslim conversion in canon law', pp. 328-30. Kedar cites Alanus, Ius naturale on C. 23 q. 4 d.p.c. 36 , as unusual in his opinion that Christian authorities may deprive obstinate Saracens of their property and subject them to corporal punishment as a means of facilitating their voluntary conversion to Christianity, but he observe that Bernard of Pavia and Raymond of Peñafort (see previous note) implicitly condone such activity too. Also unusual is the opinion expressed by Pierre d'Estaing in his commentary on Clem. 5.2.un, paraphrased in Gilles, 'Legislation et doctrine canoniques', p. 205: because Jews and Saracens are 'slaves' of Christian rulers, they have no rights over their children and for that reason Christian rulers may seize and baptize Jewish and Saracen children. ${ }_{76} 3$ Lateran (1179), c. 26 (Alberigo, decrees, p. 224; 1 Comp. 5.5.5, X 5.6.5); Montpel-
batize Jish and

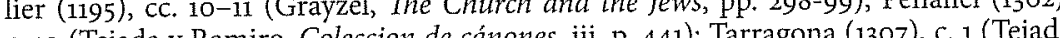
c. 10 (Tejada y Ramiro, Coleccion de canones, iii, p. 441); Tarragona (1307), c. 1 (Tejada y Ramiro, Coleccion de cánones, vi, p. 63). Support for poor

(1322), c. 22 (Tejada y Ramiro, Coleccion de canones, ili, pp. 500-1).
77 Innocent IV, Apparatus, on X 3.42.1 (labelled c. 2 in Frankfurt 1570 ed., p. 555v). belli. $7^{8}$ Christians must similarly allow their Saracen slaves to convert to Christianity. Popes, councils and canonists seek to overcome resistance on the part of slaveholders not only by threatening excommunication, but also by stipulating that such converts remain slaves, even in regions where Christian slavery is not customary. ${ }^{79}$ Innocent IV also holds that churches must provide clerics who can minister to Saracen converts in their own language. ${ }^{80}$

Marriages contracted by Saracens before their conversion raise a number of thorny questions for canonists. May a baptized Saracen remain married to a spouse to whom he is too closely related according to canon law, such as a first cousin? Yes, according to popes Clement and Innocent III. May such a Saracen remain married to a spouse who refuses to accept baptism but wishes to remain with her newly Christian husband? Yes, lest the wife persuade her husband

${ }_{78}$ Innocent IV, Apparatus, on X 3.34.8. See also the bull Cum hora undecima, originally issued by Gregory IX in 1235 and reissued in a revised form by Innocent IV in 1245 and, in that form, by many subsequent popes. On this bull, which refers first and foremost to missionary activity in Saracen lands, see Muldoon, 'Avignon papacy', pp. 143-46. Innocent discourages belligerence toward Saracens if their conversion might 143-46. Innocent discourages belligerence toward Saracens if their conversion might
be secured by other means: Apparatus on X. 3.42.3 (p. $456 \mathrm{r}$ in the Frankfurt 1570 ed., be secured by other means:
which identifies this as c. 4 )

which identifies this as c. 4). alonian custom of not holding Christian slaves (a custom also evident in the Kingdom of Jerusalem), but he does not require Christian masters to free converted slaves. Pope Gregory IX, in contrast, explicitly declares that non-Christian slaves owned by Christian masters remain slaves after baptism. This opinion underlies the works of Goffredus Tranensis, Summa super titulis Decretalium, 1519 (repr. Aalen, 1968), 5.4.8 (p. 206v) and Hostiensis, Summa aurea, Lib. 5, De servis Judaeorum et Saracenorum $\$ 5$ (col. 1528). Its influence may also be seen in the work of various regional councils. The Council of Tarana (1329, c. 24. Mansi, Sacrorum conciliorum nova et amplis-

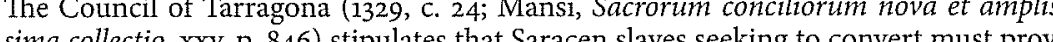

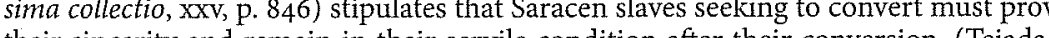
their sincerity and renain in their servile condition after their conversion. (Tejada Ramiro provides only the summary rubric of this canon; many of the canons promulgated in 1329 were first promulgated at earlier councils of Tarragona, but Thave been unable to find this canon elsewhere in Tejada y Ramiro's collection.) Odo of Châteauroux's Statute of Jaffa (1253, text in Mansi, Sacrorum conciliorum nova et amplissima collectio, xxvi, pp. 317-18), echoed by a 1298 synod of Nicosia (text in Mansi, Sacrorum conciliorum nova et amplissima collectio, xxvi, p. 350), excommunicates masters who prevent their slaves from converting. See Kedar, Crusade and mission, pp. 76-78, 14651; editions of Gregory IX's letters on this subject appear on pp. 212-15. See also R.I. Burns, 'Journey from Islam. Incipient cultural transition in the conquered Kingdom of Valencia (1240-1280)', Speculum 35 (1960) 337-56, pp. 342-45.

so Innocent IV, Apparatus, on X (1960) 34 Lateran, $c$. Alberigo, Decrees, p. 239). The Councils of Valladolid (1322, $c .32$, Tejada $y$ Ramin Colecion de canones, p. 501) and Caragena (1475, c. go; Molina Sin odo de la Diócesis de Cartagena, p. 157 ) p. 501) and Cartagena (1475, c. 90 ; Molina, Sinodo de la Diocesis de Cartagena, p. 157) require those who minister to Jewish and Saracen converts to secure specific authorzation before doing so. 
to renounce his conversion so as not to lose her. May such a Saracen remarry if his spouse refuses to remain with him, gives offense to Christianity, or seeks to seduce her husband into mortal sin? Yes again, despite the Church's principled opposition to serial monogamy; popes draw here on 1 Cor 7:15. ${ }^{81}$ May a polygamous Saracen retain all of the wives he married before his conversion? No: polygamy, according to Innocent, contravenes the laws of nature incumbent upon all of humanity, and for that reason only the Saracen's first wife is legally married to him. $^{82}$

Conversion from Christianity to Islam is completely unacceptable. The subject never appears in the Decretum and, within the Decretals, appears solely in a rhetorical context: a woman fed up with her husband's unwillingness to honor their pact of celibacy says with her husband rather become a Saracen than live with him. ${ }^{83}$ Friars in Tunis, in contrast, pose a question regarding actual converts to in Tunis, in continue to associate with them? Raymond of Peñafort, reporting the reply of Pope Gregory IX, answers in the affirmative. He stipulates, however, that such communication should be intended to lead the converts back to the Christian fold or should result from necessity, such as the need to obtain food from the

8: All three questions are addressed by both Clement (JL 16595, 2 Comp. 3.20.1) All the and Innocent (Poth includes only lnnocents decrests this decretal on the legitimacy of children born to consanguineous converts appear as X 4.17.15. Clement, responding to questions from Spain, addresses Jewish and Saracen converts simultaneously; Innocent III, responding to questions from the titula bishop of Tiberias, refers only to presumably Islamic 'pagans.' Innocent also addresses these issues in X 4.14.4 (3 Comp. 4.10.1; Potthast, Regesta pontificum, 507) and X 4.19.7 (3 Comp. 4.14.1; Potthast, Regesta pontificum, 684). Another case involving the conversion of a married Saracen is addressed by Celestine III in X 3.33.1 (whose other contents are discussed at $n$. 19 above): a married Christian who abandons both his wife and Christianity may, if that wife is deceased, retain the second wife he took as wife and Chine returns to the Christian fold. On all of these canons and the opinan infidel wh in heters, see Kedar, 'Muslim conversion in canon law', pp. 321-26. For ions of their interive context of the interpretive a detailed analysis of Innocents opinions within the con infidels'. M. Verbaarschot, 'De tion, see Muldoon, 'Mima iuridica natura impedimenti consanguinitatis, Ephemenin the broader context of legal (1954) 697-739, places the first two cited can

discourse about consanguineous marriage. ${ }_{82}$ X 4.19.7-8; see the previous note. Innocent regards acts of polygamy

the Old Testament as divinely authorized exceptions to this universal rule.

${ }_{3} 3$ Comp. 2.15.10, X 2.24.24; this reference appears in a decretal of Innocent IIr to the archbishop of Tarragona dated 1203, Potthast, Regesta pontificum, 1946. See Kedar Muslim conversion in canon law, p. 330. converts. Similarly, a Christian whose spouse 'falls into heresy' may remain married so long as the Christian is not at risk of insulting God or being dragged into mortal $\sin .{ }^{84}$ These scenarios, of course, could never unfold in Christian Europe, where ecclesiastical and civil authorities would instead pressure the converts directly, even to the point of imposing capital punishment upon those who refuse to submit once more to the authority of the Church.

The adoption by Christians of Saracen practices constitutes a more widespread concern. A Hungarian council calls for the expulsion of Saracens who, after their conversion, revert to their ancestral law by performing circumcision. ${ }^{85}$ Raymond of Peñafort warns that Christians living under Saracen rule who venerate 'Mahumatus' or their shrine 'Almeadi', or who behave in public as Saracens and in private as Christians, are apostates if they do so out of a desire to revere God but merely commit a mortal sin if they do so out of fear. ${ }^{86}$ Various Spanish councils prohibit Christians from attending either Jewish or Saracen weddings or funerals; the Council of Cartagena explains that this prohibition is intended to prevent simple-minded Christians from being led into unbelief. ${ }^{87}$ Commentators hold that clerics who bequeath a portion of their inheritance to Jewish or Saracen relatives are subject to anathema, even post mortem; this rule is derived from a canon that refers to pagan relatives. ${ }^{8}$

${ }_{84}$ Raymond of Peñafort, Responsiones ad dubitabilia $\$ \$ 10-11$ (cols 1027-28); see Tolan, 'Taking Gratian to Africa', pp. 58-59.

${ }^{95}$ Council of Szabolcs (1092), c. 9; see J.M. Bak, G. Bónis and J.R. Sweeney (trans), The laws of the medieval kingdom of Hungary $1000-1301,2^{\text {nd }}$ revised ed., Idyllwild CA, 1999, p. 55 .

Raymond of Peñafort, Summa de paenitentia 1.7.7 (cols 334-35). Raymond, Responsiones ad dubitabilia $\$ 16$ (col. 1030), also accommodates fear of Saracens by allowing the pre-dawn performance of mass for nervous Christians living in Islamic lands; see Tolan, 'Taking Gratian to Africa', pp. 57-58.

${ }_{87}$ Valladolid (1322), c. 22 (Tejada y Ramiro, Coleccion de cánones, iii, p. 400); Cartagena (1475), c. 89 (Molina, Sínodo de la Diócesis de Cartagena, p. 157); Avila (1481), c. 2 (García y García, 'Jews and Muslims', p. 46).

${ }_{88}$ Bernard of Pavia, Summa decretalitum, 5.4 .4 (p. 211), and Raymond of Peñafort, Sumpra de paenitentia $143(\mathrm{col} 311)$ both base this rule on a canon promulgated Sur Carthage in 401 (1 Comp. $5.68, \mathrm{X} 5.7 .5)$. The Cor García, 'Tews and Muslims', pp. $48-49$ ) extends this prohibition to all Christians. 
Should not Saracens be less objectionable than Jews?

Oldradus de Ponte offers a revealing response to the question of whether a Jew should be punished for converting to the religion of the Saracens. He begins his response by saying that no punishment is warranted because Judaism and Islam are equivalent: 'If each is in a state of damnation it does not matter to which sect he belongs because there is no distinction between equivalents.89 This notion of equivalence evidently underlies the application to Saracens of Jewry law. Oldradus, however, proceeds to sound a different note: 'the Saracen sect is not as bad as that of the Jews', as attested by the fact that Jesus (Mt 11:24) and Ezekiel (Ezek 16:51) condemn the Jews as worse even than the gentiles of Sodom.90 'One ought not be punished, therefore, for choosing the path of lesser evil'.

The notion that Jews occupy a unique position at the nadir of human society and morality, while Islam constitutes a 'lesser evil', is commonplace in sources from the first millennium of Christianity. This concept is submerged in normative discourse, which equates Jews and Saracens, but it resurfaces in Oldradus' responsum and, even more forcefully, in a responsum by the Spanish canonist Alfonso de Madrigal (d. 1455), which forbids conversion from Islam to Judaism. Alfonso argues that those who choose a false religion are more contemptible than those who happen to be born into such a religion and that the choice of a religion other than Christianity constitutes a forbidden act of blasphemy against Christianity. After mounting arguments that explicitly apply both to Jews who convert to Islam and to Saracens who convert to Judaism, Alfonso proceeds to demonstrate that Judaism is inferior to Islam. He supports this assertion both with arguments

${ }_{89}$ Oldradus de Ponte, Consilium 51, in Zacour, Jews and Saracens, pp. 77 (Latin), 2. (English): cited translations are by Zacour. On this consilium, see also W. Stalls, 'Tewish conversion to Islam. The perspective of a quaestio', Revista Española de Teologia gia 43 that the ated, that the Che the error of other of choice allows Jews to opt either forled taiths. An edict promnlga Council of Tarragona of 1233, in contrast, prohibits conversion from Islam to Judaism or vice versa (Grayzel, The Church and the Jews, pp. 324-25, who labels this c. 22,
Tejada y Ramiro, Coleccion de cánones, iii, p. 366, c. 19).

${ }_{90}$ Oldradus draws here on Augustine, De baptismo 6.86 (C. 1. q. 1 C. 37); for a similar opinion by Agobard of Lyons that juxtaposes Jews and Saracens, see Freidenreich, 'Muslims in canon law', p. 97 in CMR 1. Oldradus also observes that the Good Friday liturgy includes a genuflection on behalf of the pagans, but not one for the Jews. ascribed to Oldradus and Ludovicus Pontanus (d. 1439) and with his own argument regarding the Jews' murder of Jesus. David Nirenberg summarizes Alfonso's argument as follows: 'how can we allow Muslims, who did not participate in the killing of the Lord, to be brought by the Jews into this status?'91

Given the unique status that Christian theology assigns to Jews, why do so many legal authorities equate Jews and Saracens? Convenience is surely a significant factor: Jewry law offers tradition-minded canonists a ready set of precedents that may be applied to new populations of subject non-Christians. ${ }^{92}$ Many canonists, moreover, evidently perceived the differences between Jews and Saracens to be irrelevant..$^{93}$ The evolution of canonical discourse about the permissibility of sharing meals with non-Christians offers an additional answer: Saracens themselves, according to medieval canonists, behave like Jews and therefore subject themselves to laws originally intended for Jews alone. ${ }^{94}$

Early commentators on the Decretum, including Rufinus (writing c. 1164), observe that canons found in this work prohibit commensality with Jews, but permit sharing meals with other non-Christians. 'That prohibition is made specifically regarding Jews', Rufinus explains, 'because through the abuse of scripture they subvert faith

${ }_{91}$ D. Nirenberg, 'Love between Muslim and Jew in medieval Spain. A triangular affair, in H.J. Hames (ed.), Jews, Muslims and Christians in and around the Crown of Aragon. Essays in honour of Professor Elena Lourie, Leiden, 2004, 149. Nirenberg, who provides an extensive summary of Alfonso's unpublished treatise, notes that he has been unable to identify the opinion of Ludovicus to which Alfonso refers. It is striking that, in Nirenberg's words, Alfonso cites as 'opprobria reserved for the Jews as marks of the servitude they incurred through deicide' many of the Jewry law regulations that had long been applied to Jews and Saracens alike. These include the requirement for distinctive clothing, segregation during Holy Week, and the bans against owning Christian slaves, employing Christian wetnurses, receiving bequests from Christians, and holding public office

${ }_{92}$ This factor is highlighted by Abulafia, 'Servitude of Jews and Muslims', p. 705

93 See D. Nirenberg 'Christendom and Islam', in M. Rubin and W. Simons (eds) Christianity in Western Europe, c. 1100-c. 1500 (Cambridge History of Christianity 4), Christianity in Western Europe,

Cambridge, 2009, 149-69, p. 153.

${ }_{94}$ For a more in-depth treatment of the material summarized in the following paragraphs, see Freidenreich, 'Sharing meals'; I place this subject in broader perspective in Foreigners and their food. Zacour, Jews and Saracens, pp. 16-22, points to a different perceived similarity between Jews and Saracens to explain their equivalent legal status, namely the rhetorical association of both communities with the biblical figure of Hagar. This suggestion, based on Oldradus' use of Hagar rhetoric, seems to be of limited value as a means of explaining canon law regarding Muslims more broadly. Legal authorities only rarely allude to Hagar and many of those who do so, including Bernard of Pavia and his successors, contrast the Hagarene ancestry of the Saracens with the Judahite ancestry of the Jews. 
in Christ in several ways and condemn the food of Christians. Gentiles, however, are not like this, and therefore we are not prohibited from going to their table.95 Bernard of Pavia - who, we have seen, equates Saracens and pagans - applies Rufinus' logic to the distinction between Jews and Saracens, permitting commensality with the latter even as he applies a variety of other Jewry laws to Saracens. According to Bernard, Saracens are less capable than Jews of subverting Christian faith. ${ }^{96}$ Huguccio, however, argues that this distinction no longer applies. 'Nearly all Saracens at the present judaize because they are circumcised and distinguish among foods in accordance with Jewish practices. I say, accordingly, that one ought to abstain from the food of such pagans - that is, those who distinguish among foods - just as from the food of Jews. ${ }^{97}$ Because Saracens behave like Jews, Huguccio argues, the same laws ought to apply to both; we observed Huguccio's use of this logic with reference to Saracen owners of Christian slaves above.

The anonymous author of Ecce vicit leo (second recension, 1210) objects to Huguccio's logic. 'The reason for this prohibition [of commensality] is that Jews have the Law and by means of it they are able more easily to lead back the hearts of the simple to their dread [rites] if they share meals with them.' Moreover, there ought to be a distinction between commensality with Jews and commensality with gentiles because 'association with [Jews] is more distasteful than with gentiles.98 Ecce vicit leo espouses the classical notion that Jews are inferior to

${ }^{9}$ Rufinus, Summa decretorum, p. 317. The canon on which Rufinus comments, C. 11 q. 3 c. 24, a translation of John Chrysostom's Homilies on Hebrews 25.3-4, permits commensality with pagans but ages such shared meals as a means of missionizing. The prohibition against commensality with Jews appears in C. 28 q. 1 C. 14 (Agde [506], c. 40)

${ }_{96}$ Bernard of Pavia, Summa decretalium 5.5.4 (p. 211). See also Summa Elegantius (Coloniensis) 7.66 (ii, p. 189), which cites the permissibility of eating with 'pagans' to demonstrate the ways in which excommunicants are inferior to 'Saracens'.

97 Huguccio, Summa decretorum on C. 11 q. 3 C. 24, cited and translated in Freidenreich, 'Sharing meals', pp. 59-60.

${ }_{98}$ Ecce vicit leo on C. 11 q. 3 c. 24 and C. 28 q. 1 c. 14; see Freidenreich, 'Sharing meals', p. 62. Page 54 of that article provides further examples of arguments that possession of the Old Testament makes Jews especially threatening to Christians. Huguccio himself interestingly, makes precisely this argument when explaining why cionverts to Christianity must divorce Jewish spouses who refuse to convert but weed convert not diverce gentile spouses (Sum hoc; this passage is reproduced in Pakter, Medienal canon law and the Jews, p. 279, n. 133). This passage, however, was evidently composed before Huguccio, parned about the 'judaizing' behaviors of the Saracens, because it advocates for the very other non-Christians, Saracens included, and holds that canon law ought to make manifest this distinction. This canonist's opinion, however, fails to sway his colleagues: nearly all other $13^{\text {th }}$-century authorities equate the status of Jews and Saracens with respect to the commensality prohibition. Because these canonists conflate Saracens and pagans, this prohibition also comes to apply to all non-Christians even those encountered during the Baltic crusades. ${ }^{99}$

Huguccio and his successors justify the equation of Jews and Saracens as a necessary response to the 'judaizing' practices of the Saracens. Christian authorities, fearful of the blurring of boundaries between their own tradition and Judaism, perceived Saracens as having succumbed to the pernicious influence of the Jews, thus forfeiting the distinctive legal status to which they would otherwise be entitled. If Saracens - and, by the faulty logic of ivory tower canonists, all pagans - now behave like Jews, and Judaism is now commonly regarded as a form of heresy, $y^{100}$ then traditional distinctions between different types of non-orthodox Christians are no longer signficant. ${ }^{101}$ This conceptual shift toward a binary classification of humanity is manifest in the famous bull of Pope Boniface VIII, Unam sanctam, which declares that there is no salvation outside the Church of Rome. ${ }^{102}$ As Oldradus observes, if all non-Christians are in a state of damnation, no normative distinction among equivalents is necessary.

distinction between Jewish slaveholders and gentile slaveholders that Huguccio rejects in the comment cited at n. 52 .

99 See the Glossa Palatina, Johannes Teutonicus, and the Ordinary Gloss on C. 28 q. 1 c. 14; Raymond of Peñafort, Summa de paenitentia 1.4.3 (col. 310); Geoffrey of Trani, Innocent IV, and the Ordinary Gloss on X 5.6.10; Hostiensis, Summa aurea, Lib. 5, De Sarracenis, s.v qualiter erga ipsos (cols 1524-25). Canonists interpreted Pope Clement III's decretal permitting commensality to missionaries on the Baltic Crusade Clem 16578,2 Comp 544 X (J) 16578, 2 Conp. 5.4.4, X 5.6.10) as an exception to he gental mensality with pagans who " see Freidenreich, Sharng meals, pp. 62-70. The Council of Avila (1481, Tit. 7, C. 3 ) also forbids commensality with Jews and Saracens alike. I am aware of only one source permitting commensality with Saracens that post-dates Ecce vicit leo: Johannes Teutonicus' anomalous gloss on Dispar (reproduced in the Ordinary Gloss), discussed above at n. 47 .

${ }^{100}$ See J. Cohen, The friars and the Jews. The evolution of medieval anti-Judaism, Ithaca NY, 1982.

${ }^{101}$ Muldoon, 'Avignon papacy', p. 149, similarly observes that the $14^{\text {th }}$-century papacy perceived no differences between infidels and schismatics, to the detriment of the Church's missionary efforts.

102 Extrav commun. 18. Potthast, Regesta pontificum, 25189. On the impact of this text on papal missions to foreign non-Christians, including Saracens, see Muldoon, 'Avignon papacy'. 
Theologically motivated anti-Judaism, however, continues to prompt canonists such as Oldradus, Alfonso and the author of Ecce vicit leo to insist upon the relative superiority of Saracens to Jews. ${ }^{103}$ Latin canon law regarding Muslims thus reveals the tensions inherent in Christian conceptions regarding Saracens and their place within the broader framework of non-Christians.

Works on Christian-Muslim relations

$1050-1200$

${ }^{103}$ This relative superiority also manifests itself in civil laws from Spain: while many laws treat Saracens and Jews alike, others fall more harshly upon the Jews. See E. Lourie, 'Anatomy of ambivalence. Muslims under the Crown of Aragon in the late thirteenth century', in idem, Crusade and colonisation. Muslims, Christians and Jews in medieval Aragon, Aldershot UK, 1990, 51-69. See also Nirenberg ('Love between Muslim and (Jew'), who proposes that the increased significance of theological considins $15^{\text {th }}$ century awa from treating Jews and Sansiderations accounts for a shift in the $15^{\text {th }}$ century away from treating lews and Saracens
as legally equivalent. 